"Analysis of the enterprise`s readiness to implement modern tools of corporate culture development"

\begin{tabular}{|c|c|c|}
\hline \multirow{2}{*}{$\begin{array}{l}\text { AUTHORS } \\
\text { ARTICLE INFO }\end{array}$} & \multicolumn{2}{|l|}{$\begin{array}{l}\text { Hanna Veretennykova } \\
\text { Viktoriia Tomakh }\end{array}$} \\
\hline & \multicolumn{2}{|c|}{$\begin{array}{l}\text { Hanna Veretennykova and Viktoriia Tomakh (2020). Analysis of the enterprise's } \\
\text { readiness to implement modern tools of corporate culture development. } \\
\text { Development Management, 18(4), 1-9. doi:10.21511/dm.18(4).2020.01 }\end{array}$} \\
\hline DOI & \multicolumn{2}{|c|}{ http://dx.doi.org/10.21511/dm.18(4).2020.01 } \\
\hline RELEASED ON & \multicolumn{2}{|l|}{ Monday, 22 February 2021} \\
\hline RECEIVED ON & \multicolumn{2}{|l|}{ Thursday, 28 May 2020} \\
\hline ACCEPTED ON & \multicolumn{2}{|l|}{ Tuesday, 11 August 2020} \\
\hline LICENSE & \multicolumn{2}{|c|}{$\begin{array}{l}\text { This work is licensed under a Creative Commons Attribution } 4.0 \text { International } \\
\text { License }\end{array}$} \\
\hline JOURNAL & \multicolumn{2}{|l|}{ "Development Management" } \\
\hline ISSN PRINT & \multicolumn{2}{|l|}{$2413-9610$} \\
\hline ISSN ONLINE & \multicolumn{2}{|l|}{$2663-2365$} \\
\hline PUBLISHER & \multicolumn{2}{|c|}{ LLC "Consulting Publishing Company "Business Perspectives" } \\
\hline FOUNDER & \multicolumn{2}{|c|}{ Simon Kuznets Kharkiv National University of Economics } \\
\hline$\sigma^{0}$ & 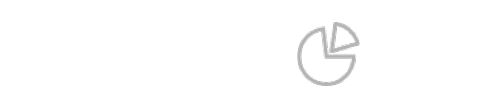 & $\begin{array}{l}\text { 三E: } \\
\text { 三E }\end{array}$ \\
\hline NUMBER OF REFERENCES & NUMBER OF FIGURES & NUMBER OF TABLES \\
\hline 37 & 0 & 3 \\
\hline
\end{tabular}

(c) The author(s) 2022. This publication is an open access article. 


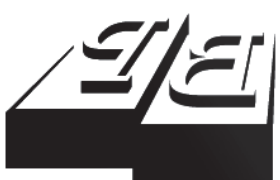

BUSINESS PERSPECTIVES

Publisher

LLC "CPC "Business Perspectives" Hryhorii Skovoroda lane, 10, Sumy, 40022, Ukraine www.businessperspectives.org

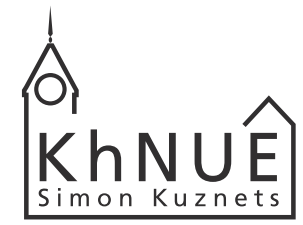

\section{S. KUZNETS KHNUE}

Founder

Simon Kuznets Kharkiv National University of Economics, Nauky avenue, 9-A, Kharkiv, 61166,

Ukraine

http://www.hneu.edu.ua/

Received on: 28th of May, 2020 Accepted on: 11th of August, 2020 Published on: 22 of February, 2021

(c) Hanna Veretennykova, Viktoriia Tomakh, 2021

Hanna Veretennykova, Ph.D. (Economics), Associate Professor, Simon Kuznets Kharkiv National University of Economics, Ukraine.

Viktoriia Tomakh, Ph.D.

(Economics), Associate Professor, Simon Kuznets Kharkiv National University of Economics, Ukraine.

\title{
ANALYSIS OF THE ENTERPRISE 'S READINESS TO IMPLEMENT MODERN TOOLS OF CORPORATE CULTURE DEVELOPMENT
}

\begin{abstract}
Corporate culture is a unique attribute of the enterprise that positively affects the socio-economic results of its activity and develops under the influence of external and internal factors. The paper suggests a group of factors influencing corporate culture that determine the effectiveness and speed of its development. This group includes the level of competence of HR managers; the level of influence on staff of formal and informal leaders and their attitude to changes; the presence of cultural bugs, the attitude of the existing culture to changes, the degree of hierarchy, the speed of communication channels, the level of staff satisfaction with the situation, the presence of feedback.

An analysis of global trends of enterprises' corporate culture development allowed formulating the following areas of its improvement for the domestic enterprises: formation of a passionate employee, ensuring a balance between work and personal life, an individual approach to personal development and the effectiveness of staff activities, the organization of a virtual office, diversification as a part of teams, and reduction of hierarchy levels. The assessment of the domestic enterprises readiness to implement measures in the framework of the identified areas indicates that the most enterprises are ready to introduce modern tools for the development of corporate culture. At the same time, the necessity was revealed to introduce the individual approach to identify areas for improving professional skills and ensuring a balance between work and personal life of employees.
\end{abstract}

Ключові слова

Класифікація JEL enterprise corporate culture, development, personnel, development impact factor, global trends, innovation, competitive advantage

D23, J53, M14, M54

Г. Б. Веретенникова (Україна), В. В. Томах (Україна)

\section{АНАЛІЗ ГОТОВНОСТІ ПІДПРИЕМСТВА ДО ВПРОВАДЖЕННЯ СУЧАСНИХ IНСТРУМЕНТІВ РОЗВИТКУ КОРПОРАТИВНОї КУЛЬТУРИ}

\section{Анотація}

Корпоративна культура є унікальною властивістю підприємства, яка позитивно впливає на соціально-економічні результати його діяльності та розвивається під впливом певних чинників зовнішнього та внутрішнього середовища. У статті запропонована група чинників впливу на корпоративну культуру, які обумовлюють ефективність та швидкість ії розвитку. До такої групи віднесено рівень компетентності менеджерів з управління персоналом; рівень впливу на колектив формальних та неформальних лідерів та їх відношення до змін; наявність культурних багів, відношення існуючої культури до змін, ступінь ієрархії, швидкість комунікаційних каналів, рівень задоволеності персоналу ситуацією, що склалася, наявність зворотного зв'язку.

Аналіз світових тенденцій розвитку корпоративної культури підприємств дозволив сформувати такі напрямки іiі покращення на вітчизняних підприємствах: формування залученого працівника, забезпечення балансу між працею та особистим життям, індивідуальний підхід до особистого розвитку та ефективності діяльності працівників, організація віртуального офісу, диверсифікація у складі команд, зменшення рівнів ієрархії. Оцінка готовності вітчизняних підприємств до реалізації заходів в рамках визначених напрямків свідчить про те, що більшість із досліджених підприємств готові до впровадження 
сучасних інструментів розвитку корпоративної культури. Разом із цим виявлено необхідність запровадження на підприємствах індивідуального підходу до визначення напрямків вдосконалення професійної майстерності та забезпечення балансу між працею та особистим життям працівників.

$\begin{array}{ll}\text { Keywords } & \begin{array}{l}\text { корпоративна культура підприємства, розвиток, персонал, чинники впливу, інновації, } \\ \text { конкурентна перевага }\end{array} \\ \text { JEL Classification } & \text { D23, J53, M14, M54 }\end{array}$

\section{ВСТУП}

Сьогодні одним з ефективних ресурсів управління підприємством є його корпоративна культура, розробка, впровадження та розвиток якої сприяє досягненню поставлених довгострокових та оперативних цілей. Розроблення відповідного до стратегії підприємства та побажань персоналу комплексу корпоративних цінностей, паралельно з розвитком системи матеріального та нематеріального стимулювання дозволяють сформувати лояльність та залученість співробітників, їх зацікавленість у зростанні економічних результатів діяльності підприємства, готовності протистояти як внутрішнім, так і зовнішнім загрозам. Укріплюючи взаємодію внутрішніх процесів на підприємстві, корпоративна культура є фактором впливу на його імідж, обумовлює надійність та етичність відносин 3 партнерами, постачальниками, споживачами, навіть з конкурентами. Конкурентна перевага, яка формується в процесі взаємодії особистих та організаційних інтересів, норм та ідеалів є унікальною, але не $є$ стабільною. Мінливість зовнішнього середовища, професійний, емоційний та соціальний розвиток персоналу, подієва історія функціонування підприємства визначають необхідність постійного вдосконалення та розвитку корпоративних відносин з урахування нових потреб та можливостей.

Отже, відстеження та аналіз основних тенденцій розвитку корпоративної культури на світовому та національному рівну є необхідною умовою своєчасної оперативної адаптації та використання найкращих інструментів в практичній діяльності вітчизняних підприємств.

\section{1. ЛІТЕРАТУРНИЙ ОГЛЯА}

Питання, присвячені визначенню сутності дефініції «корпоративна культура», їі складовим елементам, взаємодії з факторами зовнішнього та внутрішнього середовища підприємств, впливу на результати їх економічної діяльності, а також оцінюванні готовності підприємств до їі формування висвітлені у значній кількості праць як вітчизняних, так і зарубіжних науковців та практиків.

Певний внесок в дослідження корпоративної культури зробили представники системного підходу, а саме: Атос, Моран, Паскаль [24], Саймон [31], Селзник [29], Харріс [12]. Прихильниками феноменологічної школи було приділено увагу проблемам особистості у контексті внутрішнього середовища (Луї, Петтигрю [25], Роббінс [27]). Представники раціонально-прагматичного підходу (Шейн [30], Пітерс, Уотерман [26]) акцентують увагу на можливості і необхідності цілеспрямованого впливу на корпоративну культуру, визначають необхідність їі гнучкості та здатності регулювати поведінку персоналу. В роботах Дистефано, Лейн [17], Оучі [23], Хофстед [13] обгрунтована необхідність дослідження корпоративної культури крізь призму крос-культурних особливостей. Вплив окремих чинників зовнішнього середовища на корпоративну культуру визначали в своїх роботах Коттлер [16], Виханський [35], Занковський [37], Співак [34] та ін.

В Україні питаннями корпоративної культури займаються такі вчені, як Близнюк [36], Дергачова [6], Отенко [22], Ринкевич [28] та інші. Разом з тим, залишається потреба у розвитку наукових досліджень не тільки теоретичного спрямування, а й розробки практичних рекомендацій щодо впровадження сучасних інструментів корпоративних взаємовідносин. 
Аналіз літературних джерел щодо методичного забезпечення процесу управління корпоративною культурою $[3,6,13,15,18,21,28]$, а саме рекомендацій з оцінювання готовності підприємств до реалізації організаційних заходів з впровадження корпоративної культури з урахуванням ї доцільності та успішності, виявив лише роботи, які опосередковано розкривають поставлене завдання. Дослідники зосереджують свою увагу на питаннях визначення сутності корпоративної культури, чинників впливу на її контекст, системі принципів та етапах процесів її формування й реалізації.

Якщо розглядати процес впровадження сучасних інструментів корпоративної культури як інноваційний проект, слід зазначити, що готовність підприємства до його реалізації має бути визначена з урахуванням певних особливостей. Теоретичні питання ідентифікації характеристик підприємства, які дозволяють оцінювати його спроможність (готовність) до реалізації інновацій, розкрито в роботах таких учених як Ястремьска, Близнюк [36], Мусійовська [19], Бузько [2], Гапоненко [10], Федулова [9] та ін. В роботі [14] розглядається алгоритм формування інтегрального показника «рівня готовності для здійснення інноваційної стратегії» і його оцінки за допомогою узагальненої функції бажаності Харингтона [11]. Смолінська [33] пропонує використання теорії нечітких множин для оцінювання рівня інноваційної спроможності підприємства. Недобєга, Наталенко [20] виокремлюють роль персоналу організації та пропонують критерії визначення його готовності до інноваційної активності, в тому числі організаційних перетворень. Разом із цим, технологія оцінювання готовності підприємств до впровадження заходів з розвитку корпоративної культури вимагає удосконалення з позицій врахування відповідності певних критеріїв виявленим сучасним тенденціям.

\section{2. МЕТА АОСЛІДЖЕННЯ}

Мета дослідження полягає в узагальненні світових тенденцій та сучасних інструментів розвитку корпоративної культури та оцінюванні готовності вітчизняних підприємств до їх впровадження в практичну діяльність.

\section{3. МЕТОДИ ДОСЛІДЖЕННЯ}

Дослідження чинників та основних напрямків розвитку корпоративної культури здійснено за допомогою методів узагальнення, аналізу та синтезу; визначення готовності підприємств до впровадження інноваційних інструментів розвитку корпоративної культури - за допомогою експертного опитування.

\section{4. РЕЗУЛЬТАТИ}

Розвиток корпоративної культури на підприємства здійснюється під впливом чинників зовнішнього та внутрішнього середовища $[1,4,7]$. До першої групи чинників належать національно-культурні особливості, менталітет, законодавче та ідеологічне підгрунтя розвитку суспільства, конкурентне середовище підприємства, його ринкові позиції. До соціальних факторів, що відображають національні та ментальні відмінності культур, дослідники відносять норми соціальної взаємодії суб'єктів економічної діяльності; бажані організаційні форми економічної діяльності; мотивацію та ставлення до праці; відношення до власності й багатства; норми і суспільні відносини у сфері підприємницької діяльності; готовність запозичити зарубіжний економічний досвід; ставлення до індивідуальної або групової діяльності $[3,13]$. Увага до національних особливостей соціально-економічного менталітету в практичному плані виявляється в зростаючому врахуванні культурологічних чинників в практиці управління підприємствами. В багатьох розвинених країнах визнається особлива роль національної культури в формуванні стійких поведінкових моделей працівників і розвитку людського капіталу, перш за все його інноваційної складової. На думку експертів $[5,15,30]$, ефективна корпоративна культура не може істотно суперечити культурі господарювання, яка склалася в країні, що пояснює популярність прикладних соціолого-антропологічних досліджень етнічних особливостей людських ресурсів в сучасній науковій практиці. 
Розглядаючи групу внутрішніх чинників, що впливають на сутність та розвиток корпоративної культури слід приділити увагу роботам Шейна, який виділяє п’ять первинних (система цінностей і поглядів, які приймаються вищим керівництвом; реакція керівництва на складні ситуації, які виникають на підприємствах; лідерство і стилі поведінки керівників; система мотивації персоналу; критерії добору, призначення, просування та звільнення з підприємства) і п’ять вторинних факторів, які визначають процес формування інноваційної корпоративної культури (організаційна структура та організаційний рівень делегування повноважень; система інформаційної комунікації та управлінські дії; зовнішній та внутрішній дизайн приміщень підприємства; історії про важливі події, діяльність керівників підприємства; формалізовані положення про філософію і цілі підприємства) [6, 32]. До факторів внутрішнього середовища також слід віднести сферу діяльності, форму власності, розмір підприємства, стадію життєвого циклу підприємства $[8,18]$, прийнятий стиль управління, якісний склад персоналу (емоційні та інтелектуальні орієнтири), наявність субкультур та динаміку їх розвитку [21, 22], стратегічні настанови підприємства, пріоритетність між людино орієнтованим та процесоорієнтованим підходом в управлінні [14]. На наш погляд, наведені вище чинники вливають на контентну сутність розвитку корпоративної культури, які доцільно доповнити групою чинників, що обумовлюють успішність процесів розвитку. До даної групи чинників слід віднести наступні: рівень компетентності менеджерів з управління персоналом; рівень впливу на колектив формальних та неформальних лідерів та їх відношення до змін; наявність культурних багів, відношення існуючої культури до змін; ступінь ієрархії; швидкість комунікаційних каналів; рівень задоволеності персоналу ситуацією, що склалася; наявність зворотного зв’язку. Врахування запропонованої групи чинників дозволить оцінити рівень успішності впровадження інноваційних інструментів з управління корпоративними відносинами на підприємстві.

Разом із виділеними чинниками керівники підприємств, в т. ч. керівники підрозділів з управління персоналу, мають здійснювати постійний моніторинг сучасних тенденцій розвитку корпоративної культури, оскільки акцентуація на застарілих культурних цінностях ускладнює залучення та утримання найкращих працівників, що негативно впливає результативність бізнесу. Глобалізація, інформатизація та технологізація суспільства, зміни у складі працездатного населення (поява на ринку праці покоління Z) вимагають від працедавців пропонувати найпрогресивніші умови співробітництва з талантами в рамках сильної та позитивної корпоративної культури. Проведений аналіз бізнес-середовища дозволив виокремити такі тенденції розвитку корпоративної культури:

1. Формування залученого працівника, тобто проактивного лояльного працівника, зацікавленого в успіху діяльності підприємства. Основними характеристиками, що притаманні такому працівнику, $\epsilon$ почуття особистої значущості для компанії, використання творчого підходу до вирішення завдань, бажання розширити зону відповідальності, самовдосконалення (емоційне та професійне), ініціативність та орієнтація на досягнення цілей. Отримання позитивних результатів та успішна самореалізація для такого працівника забезпечують позитивні психологічні надбання, які формують внутрішні мотиви підвищення продуктивності праці. Основною концепцією створення залученого працівника $€$ формування певного середовища, в якому він із задоволенням розкриває свої професійні, творчі здібності. Основними компонентами такого середовища виступають стратегічні лідери, які поважають та оцінюють вклад працівника; операційні менеджери, які дозволяють підлеглим розширити зону компетенцій; наявність цінностей, яких дотримуються, а не регламентують; можливість коментувати, пропонувати, обговорювати.

2. Забезпечення балансу між працею та особистим життям, оскільки продуктивність втомленого працівника знижується. Зарубіжні працедавці намагалися урізноманітнити робочі місця, створивши нестандартні для офісного середовища ділянки для активного відпочинку, але такі нововведення не в змозі повністю замінити життя працівників за межами підприємства. Отже, сьогодні приділяється увага таким можливостям як гнучкий графік, регламентоване у часі користування корпоративною поштою, відстеження дотримання норм часу, додаткова тривала відпустка за певні досягнення, яка дозволяє «перезавантажитися»; зонування робочого приміщення, спеціалізовані тренінги 3 емоційного інтелекту, тайм-менеджменту, різноманітні медитативні практики. Відсутність стресу та відчуття благополуччя також підтримуються політикою «відкритих дверей», яка забезпечує легке спілкування, зворотній зв’язок, заохочення ведення здорового способу життя. 
3. Особистий розвиток та ефективність працівників передбачає використання індивідуального підходу до: визначення напрямків вдосконалення професійної майстерності (наставництво, коучинг, менторинг, самостійне навчання) та визначення індивідуальних факторів, що обумовлюють ефективну діяльність працівника (час роботи, умови праці, робоче місце). Розробка персональних планів розвитку персоналу забезпечить вибір найбільш доцільних методів управління ним. Участь персоналу у розробці такого плану підвищує його відповідальність, наполегливість в процесі отримання та розвитку навичок. Розроблені цілі, терміни, етапи та напрямки мають бути під контролем працівника та його керівника. Розуміння працівника, що підприємство інвестує в нього гроші, обумовлює розуміння, що підприємство цінує його як професіонала. В свою чергу, таке ставлення до персоналу є додатковим інструментом формування лояльності до підприємства.

4. Віртуальний офіс стає розповсюдженим явищем, що дозволяє підприємству скорочувати адміністративні витрати з одного боку, а працівнику обирати комфортне місце розташування та час для виконання своїх професійних обов'язків, вирішення поставлених завдань, з іншого боку. Такий підхід організації бізнес-процесів передбачає орієнтування на отримані результати, при цьому відсутня необхідність контролювати робочий час, але працівники, які обирають такі умови співпраці мають володіти такими якостями як самосвідомість та самодисципліна. Не дивлячись на зазначені переваги, керівники таких організацій спрямовують свої зусилля на розвиток почуття культури, самобутності організації, організовують зв’язок між учасниками і командами. Особливу увагу приділяється програмам розвитку співробітників і командоутворення.

5. Диверсифікація у складі команд. Таке ставлення при формуванні командного складу обумовлено необхідністюрозглядупроблемизрізнихсторін.Наявність в командіучасників різнихфункціональних напрямків дозволяє сформувати комплексне бачення ситуації. Залучення до командної роботи різних за профілем спеціалістів дозволяє генерувати більшу кількість ідей, розробляти альтернативні шляхи вирішення проблеми. Використання таких команд в рамках одного підприємства паралельно 3 розвитком команди сприяє розвитку кожного члена команди. Керівники організацій націлені на створення культури, в якій співробітники готові брати на себе відповідальність та працювати разом, щоб досягти бажаного результату; підняти командний дух, що мотивує всіх співробітників удосконалювати свої навички; познайомити людей з різних відділів.

6. Зменшення рівнів ієрархії дозволяє підприємствам бути гнучкими, більш ефективно розподіляти ресурси, швидко реагувати на зміни зовнішнього середовища. Матрична організаційна структура підприємства передбачає, що працівник співпрацює з декількома керівниками, що обумовлює виникнення проблем комунікації. В такому разі доцільно впроваджувати міжфункціональне навчання команди.

Виявлені тенденції свідчать про усвідомлення більшістю керівників підприємств необхідності перемістити пріоритетність уваги із задоволення споживачів на формування залученого працівника Критерієм успішності функціонування підприємств сьогодні розглядається персонал, оскільки рівень його залученості обумовлює результати його діяльності.

Відповідно до поставленої мети у дослідженні було визначено готовність вітчизняних підприємств до впровадження основних інструментів розвитку корпоративної культури в рамках виявлених тенденцій. При цьому корпоративну культуру розглянуто як інноваційний продукт підприємства, а їі реалізацію як відповідний інноваційний проект.

Для визначення готовності підприємств до впровадження інноваційних заходів з розвитку корпоративної культури була використана технологія, розповсюджена в практичній діяльності консалтингових агентств, заснована на залученні експертів. В даному дослідженні було проведене опитування 40 експертів, у якості яких виступили менеджери вищої та середньої управлінської ланки 20 підприємств Харківського регіону. Респонденти мали оцінити ступінь прояву кожної запропонованої вимоги щодо можливості впровадження кожного інноваційного інструменту з розвитку корпоративної культури. До використання було запропоновано оцінки від 2 до 5, при цьому: «5» - задана вимога на підприємстві повністю проявляється; «4» - задана вимога проявляється не повною мірою; «3» - задана вимога проявляється слабко; «2» - задана вимога зовсім не проявляється. 
Досліджувані критерії, які було визначено на основі аналізу сутності процесу прийняття рішень щодо визначення готовності підприємства до впровадження інноваційних проектів, наступні: сумісність інноваційного заходу (I3) 3 поточною бізнес-стратегією (або доцільність змін в бізнес-стратегії; відповідність I3 основним побажанням персоналу; готовність персоналу до впровадження І3; низький ступінь ризикованості I3; високий потенціал зростання ефективності діяльності підприємства; значний вплив на рівень лояльності, залученості персоналу; наявність організаційних можливостей; наявність налагодженого механізму збору, аналізу й обробки інформації з управління персоналом; відсутність необхідності залучення сторонніх консультантів для вирішення певних задач; наявність на підприємстві достатнього фонду фінансування корпоративних заходів; високий ступінь взаємодії персоналу в процесі реалізації інноваційних заходів.

Загальна оцінка ступеня готовності підприємства розраховувалась як середньозважений бал.

Як інноваційні заходи було розглянуто сучасні світові тенденції розвитку корпоративної культури, а саме: формування залученого працівника (А); забезпечення балансу між працею та особистим життям (Б); особистий розвиток та ефективність працівників (В); впровадження віртуального офісу (Г); диверсифікація у складі робочих команд (груп) (Д); зменшення рівнів ієрархії управління (Ж).

Ступінь готовності підприємства до інноваційних заходів з розвитку корпоративної культури було оцінено якісно відповідно до шкали, наведеної у Таблиці 1.

Таблиця 1. Якісна інтерпретація показника готовності підприємства до впровадження інноваційних заходів з розвитку корпоративної культури

Джерело: Складено авторами на основі [14].

\begin{tabular}{|c|c|}
\hline Значення показника готовності & Характеристика готовності \\
\hline $5.00-4.25$ & дуже висока \\
\hline $4.24-3.50$ & висока \\
\hline $3.49-2.75$ & помірна \\
\hline $2.74-2.00$ & низька \\
\hline
\end{tabular}

Процес оцінювання готовності підприємства до впровадження інноваційних заходів з розвитку корпоративної культури та отримані результати продемонстровано на прикладі одного $з$ досліджених підприємств - ПАТ «Харківміськгаз» (Таблиця 2).

Таблиця 2. Оцінка готовності ПАТ «Харківміськгаз» до впровадження інноваційних заходів 3 розвитку корпоративної культури

Джерело: Складено за результатами дослідження авторів.

\begin{tabular}{|c|c|c|c|c|c|c|}
\hline \multirow[t]{2}{*}{ Критерії, що оцінюються } & \multicolumn{6}{|c|}{$\begin{array}{c}\text { Оцінка відповідності критеріям } \\
\text { в рамках тенденцій розвитку } \\
\text { корпоративної культури }\end{array}$} \\
\hline & A & Б & B & $\Gamma$ & Д & Ж \\
\hline $\begin{array}{l}\text { Сумісність ІЗ з поточною бізнес-стратегією (або доцільність змін в } \\
\text { бізнес-стратегії }\end{array}$ & 4 & 4 & 4 & 2 & 4 & 3 \\
\hline Відповідність IЗ основним побажанням персоналу & 3 & 4 & 3 & 1 & 2 & 2 \\
\hline Готовність персоналу до впровадження I3 & 3 & 2 & 2 & 2 & 2 & 2 \\
\hline Низький ступінь ризикованості I3 & 3 & 2 & 3 & 2 & 3 & 3 \\
\hline Високий потенціал зростання ефективності діяльності підприємства & 4 & 2 & 2 & 2 & 2 & 2 \\
\hline Значний вплив на рівень лояльності, залученості персоналу & 3 & 1 & 3 & 1 & 1 & \\
\hline Наявність організаційних можливостей & 2 & & & 1 & & \\
\hline $\begin{array}{l}\text { Наявність налагодженого механізму збору, аналізу й обробки інформації } 3 \\
\text { управління персоналом }\end{array}$ & 2 & 2 & 1 & 2 & 1 & 2 \\
\hline $\begin{array}{l}\text { Відсутність необхідності залучення сторонніх консультантів для вирішення } \\
\text { певних задач }\end{array}$ & 4 & 4 & 4 & 4 & 3 & 4 \\
\hline $\begin{array}{l}\text { Наявність на підприємстві достатнього фонду фінансування корпоративних } \\
\text { заходів }\end{array}$ & 3 & 2 & 2 & 2 & 2 & 2 \\
\hline Підсумковий рейтинг & 3.10 & 2.56 & 2.67 & 1.90 & 2.22 & 2.50 \\
\hline
\end{tabular}


На підставі отриманої оцінки ступеня готовності підприємства можна зробити наступний висновок: ПАТ «Харківміськгаз» за всіма напрямками дослідження характеризується помірним та низьким рівнем готовності, що обумовлено відсутністю зацікавленості керівництва підвищувати стандарти надання послуг та кваліфікацію й лояльність власного персоналу.

Узагальнені результати проведеного опитування щодо готовності 20 підприємств Харківського регіону до впровадження заходів з розвитку корпоративної культури в рамках існуючих світових тенденцій наведено в Таблиці 3.

Таблиця 3. Оцінка готовності підприємств Харківського регіону до реалізації заходів з розвитку корпоративної культури за основними світовими тенденціями

Джерело: Складено авторами

\begin{tabular}{|c|c|c|c|c|}
\hline \multirow{2}{*}{ Назва тенденції } & \multicolumn{4}{|c|}{ Питома вага підприємств в загальній кількості за рівнем готовності, \% } \\
\hline & Дуже високий & Високий & Помірний & Низький \\
\hline Формування залученого працівника & 25 & 25 & 35 & 10 \\
\hline $\begin{array}{l}\text { Забезпечення балансу між працею } \\
\text { та особистим життям }\end{array}$ & 10 & 27 & 23 & 40 \\
\hline $\begin{array}{l}\text { Особистий розвиток та } \\
\text { ефективність працівників }\end{array}$ & 7 & 10 & 34 & 49 \\
\hline Віртуальний офріс & 19 & 27 & 33 & 21 \\
\hline Диверсифрікація у складі команд & 25 & 35 & 20 & 20 \\
\hline Зменшення рівнів ієрархії & 45 & 28 & 17 & 10 \\
\hline Середнє значення & 21.83 & 25.33 & 27.00 & 25.00 \\
\hline
\end{tabular}

Аналіз отриманих даних за середньо узагальненими значеннями свідчить про рівномірний розподіл підприємств щодо рівня готовності до впровадження змін у корпоративну культуру в цілому, але детальний розгляд кожного інноваційного напрямку виявляє негативні тенденції щодо відсутності гнучкості політики управління персоналом та ігнорування змін зовнішнього середовища стосовно кадрових питань. Низький рівень готовності до змін спостерігається за такими напрямками як «забезпечення балансу між працею та особистим життям» (40\% підприємств) та «особистий розвиток та ефективність працівників» (49\% підприємств), що обумовлено політикою отримання максимального прибутку за умов мінімізації витрат: трудові ресурси розглядаються лише як засоби виробництва, використання яких має принести очікуваний фінансовий результат. Більшість підприємств (73\%) за напрямком «зменшення рівнів ієрархії» має високий та дуже високий рівень готовності, при цьому слід зазначити, що до цієї групи не увійшли представники держсектору. Структурний аналіз груп підприємств за кожним напрямком підтвердив, що саме державні та комунальні підприємства не є гнучкими, бюрократичні (ієрархічні) тенденції їхного функціонування є стійкими, що не дозволяє створювати додаткові конкурентні переваги або збільшувати споживчу цінність послуг чи товарів. Представники малого та середнього бізнесу в умовах несприятливого зовнішнього середовища (політична криза, епідемічні обставини, економічна нестабільність) позитивно ставляться до інноваційних змін, для яких характерне мінімальне фінансування (віртуальний офіс, диверсифікація у складі команд, зменшення рівнів ієрархії). Усвідомлення більшістю менеджерів доцільності розвитку корпоративної культури на вітчизняних підприємств відповідно до світових тенденцій та намагання впроваджувати такі інновації в практичну діяльність стикається з негативним впливом факторів як внутрішнього, так і зовнішнього середовища підприємства, які заважають або затримують реалізацію інноваційних заходів з розвитку корпоративної культури.

\section{ВИСНОВКИ}

За результатами проведеного дослідження визначено, що корпоративна культура $є$ динамічною

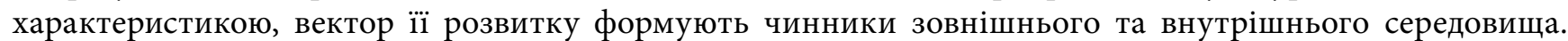
При плануванні програми розвитку корпоративної культури необхідно враховувати не лише означені 
чинники, а й розглядати групу чинників, які обумовлюють успішність та ефективність самого процесу розвитку. До групи таких чинників доцільно віднести рівень компетентності менеджерів з управління персоналом; рівень впливу на колектив формальних та неформальних лідерів та їх відношення до змін; наявність культурних багів, відношення існуючої культури до змін; ступінь ієрархії; швидкість комунікаційних каналів; рівень задоволеності персоналу ситуацією, що склалася; наявність зворотного зв'язку. Їх аналіз дозволить визначити інтенсивність, надійність та результативність впровадження системи заходів з розвитку корпоративних відносин.

Основними світовими тенденціями розвитку корпоративної культури підприємств визначено: формування залученого працівника, забезпечення балансу між працею та особистим життям, індивідуальний підхід до особистого розвитку та ефективності діяльності працівників, організація віртуального офісу, диверсифікація у складі команд. зменшення рівнів ієрархії. Оцінка готовності вітчизняних підприємств до реалізації заходів в рамках визначених тенденцій свідчить про те, що більшість з досліджених підприємств готові до впровадження сучасних заходів з розвитку корпоративної культури, проте існують проблеми із забезпеченням гнучкості політики управління персоналом. Виявлено, що у $49 \%$ підприємств не використовується індивідуальний підхід до визначення напрямків вдосконалення професійної майстерності та виявлення факторів, що обумовлюють ефективну діяльність працівників, а у $40 \%$ підприємств не забезпечується баланс між працею та особистим життям працівників, що перешкоджає розвитку корпоративної культури.

Перспективи подальших досліджень полягають у розробці стратегії розвитку корпоративної культури підприємства з урахуванням основних складових його готовності до впровадження необхідних змін щодо управління персоналом.

\section{AUTHORS CONTRIBUTIONS}

Conceptualization: Hanna Veretennykova.

Data curation: Viktoriia Tomakh.

Formal Analysis: Hanna Veretennykova.

Funding acquisition: Viktoriia Tomakh.

Methodology: Hanna Veretennykova.

Software: Hanna Veretennykova.

Writing - original draft: Hanna Veretennykova.

\section{СПИСОК ЛІТЕРАТУРИ}

1. Armstrong, M. (2009). Praktika upravleniya chelovecheskimi resursami [The practice of human resource management] (1040 p.). St. Petersburg: Piter Press. (In Russian)

2. Buzko, I. (2002). Strategicheskoye upravleniye investitsiyami i innovatsionnaya deyatelnost predpriyatiya [Strategic investment management and innovative activities of the enterprise] (176 p.). Lugansk: VUNU im. V. Dalya. (In Russian)

3. Cameron, K., \& Quinn, R. (2011). Diagnosing and Changing Organizational Culture: Based on the Competing Values Framework (288 p.). New Jersey: John Wiley \& Sons. Retrieved from https://cutt.ly/bjn2Gu0

4. Denison, D. (1984). Bringing corporate culture to the bottom line. Organizational Dynamics, 13(2), 5-22. https://doi.org/10.1016/00902616(84)90015-9

5. Denison, D. (1990). Corporate culture and organizational effectiveness. New York: John Wiley \& Sons.

6. Derhachova, V., \& Fedirko, H. (2018). Features of formation of corporate culture at the enterprises of Ukraine. Economic Bulletin of NTUU «KPI», 15, 1-8. (In Ukrainian). https://doi.org/10.20535/2307-5651.15.2018.135694

7. Elvesson, M. (2005). Organizatsionnaya kultura [Organizational culture] (460 p.). Kharkov: Humanitarian Center. (In Russian)

8. Engelen, A., Flatten, T., Thalmann, J., \& Brettel, M. (2014). The effect of organizational culture on entrepreneurial orientation: A comparison between Germany and Thailand. Journal of Small Business Management, 52(4), 732-752. https://doi.org/10.1111/jsbm.12052

9. Fedulova, I. (2009). Obhruntuvannia napriamiv innovatsiinoho rozvytku pidpryiemstv khliborobnoi haluzi [Substantiation of directions of innovative development enterprises of the grain industry] (512 p.). Kyiv: NUHT. (in Russian)

10. Gaponenko, A. (2008). Upravleniye znaniyami. Kak prevratit znaniya v kapital [Knowledge management. How to turn knowledge into capital]. Moskva: Eksmo. (In Russian)

11. Harrington, E. (1965). The Desirability Function. Industrial Quality Control, 21(10), 494-498. 
12. Harris, P., \& Moran, R. (1996). Managing Cultural Differences. Houston: Gulf Publishing Co.

13. Hofstede, G. (2011). Dimensionalizing Cultures: The Hofstede Model in Context. Online Readings in Psychology and Culture, 2(1), 1-7. https://doi.org/10.9707/2307-0919.1014

14. Hovorukha, Zh. (2012). Diahnostyka rivnia hotovnosti pidpryiemstva do zdiisnennia innovatsiinoi stratehii [Diagnosis of the level of readiness of the enterprise to implement an innovation strategy]. Agrosvit, 15, 34-39. (In Ukrainian). Retrieved from http://www.agrosvit. info/?op $=1 \& \mathrm{z}=402 \& \mathrm{i}=7$

15. Idris, S., Wahab, R., \& Jaapar, A. (2015). Corporate cultures integration and organizational performance: A conceptual model on the performance of acquiring companies. Procedia - Social and Behavioral Sciences, 172, 591-595. https://doi.org/10.1016/j.sbspro.2015.01.407

16. Kottler, J., \& Heskett, J. (1992). Corporate culture and Performance (224 p.). New York: Free Press.

17. Lane, H., \& DiStefano, J. (1988). International Management Behavior (391 p.). Toronto: Nelson.

18. Millington, M., \& Schultz, J. (2009). The Challenge of Organization Culture in Quality Assurance Implementation. Journal of Rehabilitation Administration, 33(2), 121-130. Retrieved from https://digitalcommons.usu.edu/sped_facpub/202/

19. Musijovska, O., \& Gudz, O. (2017). Innovative susceptibility and innovative ability in the process of formation of innovative policy of enterprise. Black sea economic studies, 18, 83-88. (In Ukrainian). Retrieved from http://www.bses.in.ua/journals/2017/18_2017/20.pdf

20. Nedobieha, O., \& Natalenko, M. (2012). The theoretical basis for determining availability of personnel of enterprises in innovative activity. Time description of economic reforms, 2(6), 131-137. (In Ukrainian). Retrieved from https://rep.polessu.by/handle/123456789/16423

21. Nongo, E., \& Ikyanyon, D. (2012). The influence of corporate culture on employee commitment to the organization. International Journal of Business and Management, 7(22), 21-28. https://doi.org/10.5539/ijbm.v7n22p21

22. Otenko, I., \& Chepeliuk, M. (2018). Korporatyvna kultura: mizhnarodnyi ta transformatsiinyi aspekty [Corporate Culture: International and Transformational Aspects] (242 p.). Kharkov: KhNEU. (In Ukrainian). Retrieved from http://repository.hneu.edu.ua/ handle/123456789/20079

23. Ouchi, W. (1982). Theory Z: How American Business Can Meet the Japanese Challenge. Boston: Addison-Wesley.

24. Pascale, R., \& Athos, A. (1981). The Art of Japanese Management (221 p.). New York: Simon and Schuster. Retrieved from https://www. amazon.com/Art-Japanese-Management-Applications-American/dp/0671225391

25. Pettigrew, A. (1979). On Studying Organizational Cultures. Administrative Science Quarterly, 24(4), 570-581. https://doi. org/10.2307/2392363

26. Piters, T., \& Uoterman, R. (1986). V poiskah effektivnogo upravleniya (Opyt luchshih kompanij) [In search of effective management (experience of the best companies)]. Moskva: Progress. (In Russian)

27. Robbins, S., \& Coulter, M. (2002). Menedzhment [Management] (888 p.). Moskva: Vilyams. (In Russian)

28. Rynkevich, N. (2019). Organizational culture of enterprises: challenges, threats and trends. Economic Herald of the Donbas, 3(57), $123-136$. (In Ukrainian). https://doi.org/10.12958/1817-3772-2019-3(57)-123-136

29. Selznick, Ph. (1992). The Moral Commonwealth: Social Theory and the Promise of Community. Berkeley: University of California Press.

30. Sheyn, E. (2007). Organizatsionnaya kultura i liderstvo [Organizational culture and leadership]. St. Petersburg: Piter. (In Russian)

31. Simon, H. (2011). Administrative Behavior. New York: Basic Books.

32. Simoneaux, S., \& Stroud, C. (2014). A strong corporate culture is key to success. Journal of Pension Benefits, 22(1), 51-53. Retrieved from http://www.aspenpublishers.com

33. Smolinska, N. (2011). Methodical approaches to assessing the level of innovation capacity of the enterpriselinskaya. Marketing and management of innovations, 4(1), 215-221. (In Ukrainian). Retrieved from https://mmi.fem.sumdu.edu.ua/journals/2011/4_1/215-221

34. Spivak, V. (2001). Korporativnaya kultura [Corporate culture] (352 p.). (In Russian)

35. Vihanskij, O., \& Naumov, A. (2001). Menedzhment [Management]. Moskva: Ekonomist. (In Russian)

36. Yastremska, O., \& Blyzniuk, T. (2008). Otsinka innovatsiinoi spryiniatlyvosti pidpryiemstva [Evaluation of innovative susceptibility of an enterprise]. Ekonomika: problemy teorii ta praktyky - Economics: problems of theory and practice, 241(4), 748-755. (In Ukrainian). Retrieved from http://www.repository.hneu.edu.ua/jspui/handle/123456789/7856

37. Zankovskij, A. (2002). Organizacionnaya psihologiya [Organizational psychology] (648 p.). Moskva: Flinta. (In Russian) 